This document is published in:

Journal of Industrial Economics (2003), 51(2), 193-213.

DOI: 10.1111/1467-6451.00198

(C) 2003 Blackwell Publishing Ltd. 


\title{
EXCLUSIVE CONTRACTS AND MARKET POWER: EVIDENCE FROM OCEAN SHIPPING*
}

\author{
Pedro L. Marín† ANd Richard Sicotte $\ddagger$
}

\begin{abstract}
There is a substantial theoretical literature on the potential effects of loyalty contracts, but relatively little empirical work. We employ the event study methodology to examine the competitive effects of exclusionary contracts in the ocean shipping industry, where they were the subject of an extended legal and political struggle. We find that some of the most important events in this conflict caused significant changes in shipping firms' stock returns, indicating exclusive contracts increased their profits. We then examine the effect of these events on net exporting industries' stock returns, and provide evidence that these contracts contributed to carriers' market power.
\end{abstract}

\section{INTRODUCTION}

THE USE OF EXCLUSIVE CONTRACTS and other loyalty-inducing instruments is one of the most controversial issues in competition policy. Despite the existence of a considerable theoretical literature, there is still much disagreement about the key question of whether the primary effect of exclusive contracts is to enhance efficiency or to contribute to market power. ${ }^{1}$ Moreover, much of the literature has focused on exclusive dealing relationships between manufacturers and retailers, although this is but one example of loyalty-based pricing policies employed by firms. ${ }^{2}$

*We would like to thank George Deltas, Herb Emery, Walter García-Fontes, Aidan Hollis, Ricardo Mora, Victor Stango, and seminar participants at the University of Calgary, the Universidade de Vigo, the Jornadas de Economía Industrial and the $27^{\text {th }}$ EARIE conferences. We would also like to thank the editor and two anonymous referees for helpful comments. Jeffrey Cronin and Amber Wallace provided superb research assistance. The research was supported by Spanish MCYT project SEC1999-1236-C02-02 and the Newcomen Society. The usual disclaimer applies.

Authors' affiliations: $\dagger$ Department of Economics, Universidad Carlos III de Madrid, Calle Madrid 126, Getafe, Madrid 28903, Spain.

email:marin@eco.uc3m.es

$\ddagger$ Department of Economics, University of Vermont, Old Mill, P.O. Box 54160, Burlington, Vermont 05405, USA.

email: rsicotte@zoo.uvm.edu

${ }^{1}$ Aghion and Bolton [1987], and Ramseyer, Rasmusen and Wiley [1991] contend that contracts can confer market power. For the opposing position, see Director and Levi [1956], and Innes and Sexton [1994].

${ }^{2}$ The literature on exclusive dealing in this regard is voluminous. See Marvel [1982], Ornstein [1989], Heide, Dutta and Bergen [1998], Slade [1998], Bernheim and Whinston [1998]. 
In this paper, we provide empirical evidence on the economic effects of exclusive contracts between firms and the ultimate consumers of their product. Empirical studies of such contracts have been relatively neglected, perhaps because of the difficulty in obtaining detailed data on the types and numbers of consumers that do and do not sign such contracts. We circumvent these problems by applying the event study methodology to a particular case of regulation and litigation that dealt precisely with the issue of exclusive contracts.

Ocean shipping cartels have employed exclusive contracts for more than one hundred years. ${ }^{3}$ The cartel carriers have never denied that the motivation for employing exclusive contracts is to deter entry. They have simply argued that competitive entry is 'destructive' and that industry selfregulation ensures the survival of regularly scheduled liner shipping services, and therefore is efficient. Consumers and rival non cartel carriers who opposed the use of these contracts charged that they contributed to market power in the industry to the detriment of competition, efficiency and consumers. Our objective is to provide evidence on the merit of these competing hypotheses.

The event study is especially well suited to our aim. In the United States, the ocean shipping industry was embroiled in an extended legal conflict during the 1950s, at the center of which were exclusive contracting practices. After years of litigation, the U.S. Supreme Court, in 1958, ruled that exclusive contracts that reduced or eliminated competition in ocean shipping were illegal. ${ }^{4}$ A political struggle ensued, which was only resolved in 1961 with the passage of amendments to the Shipping Act that legalized the use of exclusive contracts.

We examine the impact on ocean carriers' stock returns of several key events in this tumultuous period, each of which transmitted information specifically on the probability that exclusive contracts would be prohibited. We find that some events resulted in significant changes in the market's assessment of firms' prospects, indicating that exclusive contracts were indeed highly beneficial to ocean carriers. We then examine the effect of these events on net exporting industries, as customers of ocean carriers. ${ }^{5} \mathrm{We}$ find strong evidence supporting the view that the primary object of exclusive contracts in ocean shipping was to augment the cartels' market power, not to enhance efficiency and provide benefits to customers.

\footnotetext{
${ }^{3}$ The ocean liner shipping industry is permitted to organize cartels (conferences) because of exemptions from competition laws in Europe, the United States, and elsewhere.

${ }^{4}$ Federal Maritime Board v. Isbrandtsen Co., Inc., 356 U.S. 481 (1958).

${ }^{5}$ We are following the precedent set by Mullin, Mullin and Mullin [1995] of analyzing the effects of events on customers so as to distinguish between market power and efficiency hypotheses.
} 


\section{ECONOMIC LITERATURE ON LOYALTY CONTRACTS}

One of the first contributions related to loyalty contracts is that of Director and Levi [1956]. Posner [1976] and Bork [1978] developed their position further. These authors maintain that contracts are not a useful device to deter entry. They argue that firms will have to compensate customers fully for their exclusive patronage and that the price, after the loyalty discount, is equal to the competitive price.

Aghion and Bolton [1987] develop a model in which an incumbent monopolist offers a contract price and also sets a penalty for breaking the contract. Successful entrants need to fix a price below or equal to the monopolist's contract price. They demonstrate that when there is uncertainty about the marginal cost of the potential entrant, the monopolist can deter entry of more efficient competitors by setting a high enough penalty, while maintaining a price above the competitive level. In Aghion and Bolton's model, the monopolist compensates the buyer fully as in Director and Levi, Posner and Bork. Despite this, the monopolist is still better off because it acquires some of the entrant's expected profits through the contract. ${ }^{6}$

Ramseyer, Rasmusen and Wiley [1991] provide an example of how exclusive contracts can result in supra-competitive prices. In their model, both the monopolist and the potential entrant face a decreasing average cost function up to some capacity, the minimum efficient scale, and constant average costs beyond that point. Accordingly, entry will occur only if its share of the aggregate demand of those customers not signing the loyalty contract exceeds the minimum efficient scale. In some cases, in equilibrium, assuming there is no coordination among consumers, the monopolist only needs to offer a small discount from the monopoly price in order to deter entry. All customers will sign the contract since they know that the monopolist can deter entry by attracting enough loyal customers such that the remaining demand is not large enough to induce entry. Consumers who do not sign pay the monopoly price, while signatories pay a slightly smaller price. In order for loyalty contracts to deter entry, the only important assumptions required are that customers cannot coordinate and that there are increasing returns to scale for some levels of production. Innes and Sexton [1994] show that if consumers can form coalitions loyalty contracts may be efficient.

Several other recent contributions, with different approaches, also have taken the position that loyalty contracts can exclude lower cost entry. Klemperer [1987] views loyalty contracts, even of a weak variety, such as airlines' frequent flier programs, as a type of artificial switching cost that raises prices above what would obtain had such contracts not been

\footnotetext{
${ }^{6}$ Aghion and Bolton [1987], p. 391.
} 
TABLE I

Size ANd Number of Approved Steamship Confer-

ENCES, I958

\begin{tabular}{lc}
\hline Number of Members & Number of Conferences \\
\hline $2-6$ & 48 \\
$7-11$ & 35 \\
$12-16$ & 24 \\
$17-21$ & 10 \\
$22-26$ & 4 \\
27 or more & 1 \\
\hline
\end{tabular}

Source: John S. McGee, Ocean Freight Rate Conferences and the American Merchant Marine, 1960,

introduced. ${ }^{7}$ Finally, Sjostrom [1988] and Yong [1996] have modeled the use of loyalty contracts in ocean transport. They both conclude that if entrants are capacity-constrained, the contracts can serve as a barrier to entry, and that consumers actually benefit from the contracts. Yong points out that the unique subgame perfect equilibrium in his model is less socially efficient than an outcome in which the lower cost entrant supplies up to its capacity, and the higher cost incumbent provides the remainder of the service. ${ }^{8}$

\section{LOYALTY CONTRACTS IN THE OCEAN SHIPPING INDUSTRY}

Since the late nineteenth century, ocean carriers have organized cartels known as shipping conferences. In Europe, Regulation 4056/86 grants shipping conferences a block exemption from Article 81(1) of the Treaty of Rome. In the United States, the Shipping Act requires that conferences submit their agreements to the Federal Maritime Commission and that, if approved, the members may engage in price and quantity fixing. Conferences are organized by route; for example, there may exist one conference covering trade between Northern Europe and the Pacific ports of the U.S. and another covering trade between Northern Europe and U.S. Gulf ports. In addition, firms do not always participate in conferences on all the routes they serve, although this was much more the case in the 1950s, the period of our analysis, than the present. Conferences are very heterogeneous in their structure and membership. Table I illustrates that most conferences in the 1950s had fewer than eleven members.

From their origins, conferences have offered loyalty contracts to their customers. The first of these to gain wide use was the deferred rebate - an

\footnotetext{
${ }^{7}$ Viard [2002] extends Klemperer's [1987] model, demonstrating that switching costs might either raise or lower prices, depending upon the relative importance of new customers in a market.

${ }^{8}$ Yong [1996], p. 123.
} 
TABLE II

Frequency Distribution of Spreads in Dual-Rate Agreements of Steamship

CONFERENCES

\begin{tabular}{lccc}
\hline No. of Conferences & Amount of Spread & No. of Conferences & Amount of Spread \\
\hline 1 & $10 \%$ & 18 & $\$ 3$ \\
1 & $12.5 \%$ & 14 & $\$ 4$ \\
2 & $15 \%$ & 8 & $\$ 4.50$ \\
17 & $20 \%$ & 5 & $\$ 5$ \\
1 & $19 \%-31 \%$ & 2 & $\$ 5.50$ \\
1 & $\$ 2$ per ton & 2 & $\$ 6$ \\
1 & $\$ 2.50$ & 2 & $\$ 20$ \\
\hline
\end{tabular}

Source: U.S. House Special Subcomm. on Steamship Conferences, 1959, p. 620.

instrument still applied by conferences in non-U.S. trades. ${ }^{9}$ Under this system, customers who patronize conference members exclusively for six months receive a rebate, usually equal to ten percent of the freight rate paid. This rebate is paid in two parts. The first half is paid after an additional six months of exclusive patronage, and the second, after yet another six-month period of loyalty. This type of contract was the subject of intense scrutiny by both the British and U.S. governments in the early part of the $20^{\text {th }}$ century. At the conclusion of a multi-year investigation, the United Kingdom's Royal Commission on Shipping Rings concluded that the deferred rebate was essential to prevent the cutthroat competition of tramp steamers. In contrast, the U.S. Congress prohibited deferred rebates in the Shipping Act of 1916.

Subsequently, many conferences in U.S. trades began to use dual-rate contracts in order to inspire customer loyalty. Under this device, conferences charge two separate rate structures, contract and non-contract rates. Table II illustrates the frequency distribution of the spread between contract and non-contract rates by conferences in 1958. Those customers who sign dualrate contracts with the conference pay the lower contract rate. If a customer violates the terms of the contract by shipping cargo on a non-conference vessel, it must pay liquidated damages. The most common damages were the payment that the client would have made had it shipped with the conference at contract rates. ${ }^{10}$ It was not unusual if the penalty was a multiple of this contract rate. It is evident dual-rate contracts are strikingly similar to the contracts modeled in the economics literature.

\footnotetext{
${ }^{9}$ Article 5(2) of European Regulation 4056/86 permits both deferred rebates and dual-rate contracts, but mandates that conferences offer exporters a choice between the two. The regulation also mandates that exporters are "released from their obligation of loyalty" if the conferences provide inadequate service.

${ }^{10}$ For a detailed description of the contract terms, see U.S. House Subcomm. on Antitrust (1962), pp. 189-209.
} 
Substantial anecdotal evidence suggests that conferences used dual-rate contracts to prevent entry. For example, during the congressional investigations of shipping conferences in the late 1950s and early 1960s, documents obtained from an ocean carrier contained an admission that "the entire contract system is a fighting measure to get rid of outside competition. ${ }^{11}$ Even the head of the Federal Maritime Board, the regulatory agency charged with policing the conference system, stated that 'the purpose and intent of the dual-rate system is to drive out non-conference competition. $^{12}$

Entry deterrence, the carriers argued, was 'indispensable to the strength of a conference,' and conferences were essential to promote rate stability and regular service. ${ }^{13}$ Shipping companies argued, therefore, that dual-rate contracts did not impede trade but instead promoted it. In particular, rate stability, if a result of conferences, encourages the signing of forward contracts between exporters and importers in much the same way that it is argued that fixed exchange rates also foment trade. There is considerable evidence that liner rates are indeed much more stable than those charged by competitive tramp shipping (which primarily serves bulk commodities such as crude oil, grain and coal). ${ }^{14}$ Further, surveys of exporters and importers show that, in addition to price, reliability and quality of service are important considerations. In a recent survey of over 250 firms that are customers of ocean shipping, thirty-one percent listed price as their top concern. Twenty-two percent listed reliability, and the remainder pointed to issues such as document quality and customer service. About fifty percent stated that they "would sacrifice a few days of shipping time for a lower price, but sixty-two percent said they were reluctant to switch carriers based solely on price. ${ }^{15}$ Such responses indicate that non price impacts of dual-rate contracts could be potentially important in determining their ultimate effect on shippers.

Some treatments of the shipping conference question in the recent economics literature, such as those by Pirrong [1992] and Sjostrom [1989], maintain that the liner shipping market has an empty core. They believe that cartels are a necessary and efficient response to the absence of a competitive equilibrium. Their position echoes the informal arguments made by executives of shipping corporations. ${ }^{16}$

${ }^{11}$ Ibid., p. 216.

${ }^{12}$ Ibid.

${ }^{13}$ U.S. House Subcomm. on Antitrust (1962), pp. 216-22, and U.S. Senate Comm. on Commerce (1961), pp. 204, 209.

${ }^{14}$ Bennathan and Walters [1969], pp. 51-59.

${ }^{15}$ Journal of Commerce, email edition, October 81999.

${ }^{16}$ U.S. House Comm. on Merch. Marine \& Fisheries (1914) and U.S. House Subcomm. on Antitrust (1962). 
The basis for our empirical investigation is an intense legal and political struggle over the use of dual-rate contracts in ocean shipping. In 1958, the United States Supreme Court ruled that conferences' use of dual-rate contracts was illegal if it had the effect of eliminating competition. Three years later, Congress approved legislation definitively legalizing dual-rate contracts with much less regard for competitive considerations.

In the 1950s, approximately one-half of steamship conferences in American trades offered dual-rate contracts. ${ }^{17}$ According to statistics compiled in 1959, in trans-Atlantic trades, more than 37,000 exporters were signatories of such contracts. More than 60,000 such contracts were in effect in U.S.-Latin American trades, and over 20,000 in U.S.-Asian commerce. ${ }^{18}$

The controversy over dual-rate contracts largely stemmed from the persistent legal complaints by the Isbrandtsen Co., an independent, nonconference carrier, against conferences' use of dual-rate contracts. In the first case, Isbrandtsen protested the Federal Maritime Board's approval of a dual-rate contract system in the North Atlantic trade. On March 21, 1951, the U.S. district court ruled that the contract's twenty percent spread was 'arbitrary and unreasonable. ${ }^{19}$ This decision was affirmed by an equally divided Supreme Court on March 10, 1952. On the same date, however, in a related case, the Supreme Court ruled that the Federal Maritime Board had to first be consulted in any decision surrounding the approval of dual-rate contracts. ${ }^{20}$ This was a major victory for the carriers since the Federal Maritime Board was openly sympathetic to carriers' arguments about the validity and justifiability of dual-rate contracts.

The most controversial case involved shipping between the United States and Japan. By the early 1950s, Isbrandtsen was carrying approximately thirty percent of all liner cargo from Japan to the U.S. Atlantic and Gulf coasts. ${ }^{21}$ Late in 1952, the Japan-Atlantic and Gulf Freight Conference announced its plan to introduce a dual-rate contract system in order to fight the non-conference carrier's gains. The Federal Maritime Board quickly granted interim approval, but Isbrandtsen successfully petitioned the courts for an injunction until the F.M.B. reached its final decision after required hearings. Without the protective shield of exclusive contracts, the conference lines initiated a price war, cutting freight rates by up to seventy percent on some commodities. After continued procedural haggling, the F.M.B. formally approved the conference's request in December 1955.

\footnotetext{
${ }^{17}$ Congressional Record, September 13 1961, pp. 18167-68.

${ }^{18}$ Ibid., p. 18176; U.S. House Subcomm. on Antitrust (1962), p. 186.

${ }^{19}$ Isbrandtsen Co., Inc. v. United States, 96 F. Supp. 883 (SDNY, 1951).

${ }^{20}$ A/S J. Ludwig Mowinckels Rederi v. Isbrandtsen Co., Inc. 342 U.S. 950 (1952); Far East Conference v. United States, 342 U.S. 570 (1952).

${ }^{21}$ Federal Maritime Board v. Isbrandtsen Co., Inc. 356 U.S. 481, at 485 (1958).
} 
Isbrandtsen immediately appealed the agency's decision to the courts, and on November 9, 1956, the Court of Appeals handed down a verdict for Isbrandtsen and against the legality of dual-rate contracts. ${ }^{22}$ It ruled that the F.M.B. could not approve dual-rate contracts, because they were not permitted to do so under the Shipping Act. On March 25, 1957, the Supreme Court announced that it would hear the case. Because the Court of Appeals had already ruled against the contracts, the granting of certiorari can be considered a victory for the appellants (the F.M.B., and by extension the carriers). However, on May 19, 1958, the Supreme Court upheld the Appeals Court's verdict, deciding that dual-rate contracts that eliminated or curtailed competition were illegal. ${ }^{23}$ That same day, the conferences' political allies in Congress introduced legislation to legalize dual-rate contracts for a period of two years, during which time Congress would investigate the issue. This legislation did not encounter serious opposition and was enacted in August 1958. ${ }^{24}$

Both the House Committee on Merchant Marine and Fisheries and the Antitrust Subcommittee of the House Judiciary Committee conducted investigations during 1959-1960. On February 15, 1961, legislation was introduced to legalize dual-rate contracts permanently. On May 4, under intense pressure from Judiciary Committee chairman Emanuel Celler and the Department of Justice, the House Merchant Marine and Fisheries Committee reported a bill instructing the Federal Maritime Board to approve only those dual-rate contracts that would not exclude independent carriers. This was a severe blow to the aspirations of the shipping industry. The House of Representatives approved the bill in June, and the legislation moved to the Senate. The Senate Commerce Committee rewrote the bill, permitting the Federal Maritime Board far more flexibility in approving dual-rate contracts than was allowed in the House version. The Senate approved the committee bill with minor amendments, and the House-Senate conference approved the Senate version with only slight changes. There was considerable speculation about whether President Kennedy would veto the bill. Yet, on September 29, 1961, the White House signaled that the President would not veto, and the bill became law in early October.

The chronology contains numerous events that conveyed information about the probability that dual-rate contracts would be prohibited. These events will be critical in our tests of whether the contracts contributed to carriers' profitability, and whether their ultimate effect is to improve efficiency or expand market power.

\footnotetext{
${ }^{22}$ Isbrandtsen Co., Inc. v. Federal Maritime Board, 99 U.S. App. D.C. 312, 239 F.2d. 933 (1956).

${ }^{23}$ Federal Maritime Board v. Isbrandtsen Co., Inc., 356 U.S. 481 (1958).

${ }^{24}$ Congress later extended the interim legislation until September 1961.
} 


\section{METHODOLOGY}

Although Fama, Fisher, Jensen and Roll [1969] first utilized event studies to test the efficient market hypothesis, since then the method has been employed widely to analyze the effects of regulation on firms' performance. ${ }^{25}$ This is accomplished by testing for the effects of specific regulatory events on time series of stock returns. The implication is that a positive regulatory development will cause an abnormally high return to occur immediately following the dissemination of the information contained in the event.

In our discussion of dual-rate contracts, we identified a period during which their very existence was called into question by legal and political challenges. By examining the effect of major events during this period on the returns of securities of members of steamship conferences that employed dual-rate contracts, we effectively test whether dual-rate contracts contributed positively to firms' profitability. If, following an event that increased the probability that dual-rate contracts would be prohibited, we observe abnormally low stock returns, then we can conclude that dual-rate contracts improve the financial prospects of conference members. ${ }^{26}$ By extension, we are also testing whether or not ocean shipping conferences were able to enforce such contracts with their customers.

The validity of such tests depends upon a careful selection of events. First, if other important occurrences took place simultaneously with the selected events, the results will be severely biased. In order to avoid this pitfall, we examined the key U.S. periodical that covers the shipping industry, the Journal of Commerce. We eliminated any potential legal or legislative events that coincided with other events of importance in the industry or to specific firms. This led to the elimination of several events. We do not consider the Court of Appeals 1956 decision, because it coincided with the outbreak of hostilities in the Middle East, which led to the closure of the Suez Canal with dramatic repercussions for international shipping. In addition, we omit from our analysis several steps in the legislative process that coincided with other important events such as maritime labor strikes, subsidy legislation, and reform of the regulatory agency.

\footnotetext{
${ }^{25}$ For a survey, see Schwert [1981]. Examples are Binder [1985], Rose [1985], Mullin, Mullin and Mullin [1995], Fisher Ellison and Mullin [1995].

${ }^{26}$ The results may underestimate the impact of dual-rate contracts if firms were able to employ an alternative means of deterring entry that served as a close substitute, such as predatory pricing. Yamey [1972], Scott Morton [1997], and Podolny and Scott Morton [1999] present evidence on predation by shipping cartels in the late nineteenth and early twentieth centuries. In particular, Scott Morton's [1997] results support the deep-pocket theory, which suggests that predation in the 1950s and 1960s may have been a viable alternative to dual-rate contracts against weakly financed entrants. The possibility did not escape the attention of Congress during its investigation in 1959-1960. See U.S. House Subcomm. on Antitrust (1962), pp. 285-298.
} 
Second, the event study method will not detect significant abnormal returns if the events were anticipated long in advance or their impact was not fully realized until much later. To address this issue, we studied different event windows; in particular, one, three and five week event windows centered on the event.

We followed the same methodology for analyzing the effect of dual rate contracts on customers. If dual rate contracts result in higher freight rates, U.S. firms would face higher costs of exporting, but their foreign competitors would also have to pay higher transport prices to ship products to the U.S. market. It follows that if dual rate contracts raise freight rates, net exporting industries would be harmed and net importing industries would benefit. The converse would be true if dual rate contracts lowered freight rates. Consequently, if we detect abnormal stock returns for firms from net exporting industries, and the signs of the coefficients are the same as for the shipping companies, we would conclude that exclusive contracts reduced costs for firms in net exporting industries, and that any market power effect was justified by efficiency improvements. If we observe instead that the coefficients are significant but with signs different from those for the shipping companies, we would conclude that customers were harmed by the contracts and anticipated benefits from their elimination.

In order to execute these tests we estimate the following regression equation:

$$
R_{i t}=\alpha+\beta R_{m t}+\sum_{k} \gamma_{k} D_{k t}+u_{i t}
$$

where $R_{i t}$ denotes the stock return in period $t$ for either firm $i$ or portfolio $i$, $R_{m t}$ is the market return in period $t, D_{k}$ are dummy variables related to the event, and $u_{i t}$ is an error term. The inclusion of the market return, $R_{m t}$, will allow us to isolate the fluctuations caused specifically by the event. ${ }^{27}$ We test one, three and five week event windows. A one week event window corresponds to a $D_{k}$ with value equal to unity for the week when event $k$ takes place and zero otherwise. Three and five week event windows set $D_{k}$ equal to unity also for one or two weeks before and after the week in which the event actually occurred.

\section{DATA}

We collected weekly stock prices from Barron's for U.S. steamship companies listed on the New York Stock Exchange for the period January 1950 to July 1962. These companies are U.S. Lines, Moore-McCormack, and American Export Lines. Table III shows the number of conferences

\footnotetext{
${ }^{27}$ See MacKinlay [1997] for an extensive review and discussion of the literature.
} 
TABLE III

FIR MS' PARTICIPATION IN CONFERENCES AND THEIR USE OF DUAL-RATE CONTRACTS

\begin{tabular}{lccc}
\hline & U.S. Lines & $\begin{array}{c}\text { Moore- } \\
\text { McCormack }\end{array}$ & $\begin{array}{c}\text { American } \\
\text { Export Lines }\end{array}$ \\
\hline $\begin{array}{l}\text { Number of conferences in which the firm participates } \\
\text { Conferences that employ dual-rate contracts }\end{array}$ & 19 & 15 & 12 \\
Per cent & $58 \%$ & 13 & 5 \\
\hline
\end{tabular}

Source: Calculated from U.S. House Subcomm. on Antitrust, 1962, pp. 50-51, 56, and 186-87.

where each of these firms was participating and the number of those that employed dual-rate contracts. Moore-McCormack participated almost exclusively in conferences using dual-rate contracts. Over one-half of the conferences to which U.S. Lines belonged employed dual-rate contracts, whereas American Export Lines was a member of such conferences fortytwo percent of the time. These three firms were large American steamship corporations that participated in conferences on nearly all of the routes where they were active. Therefore, it is logical to conclude that they had a considerable stake in the dual-rate system to the extent it supported the conference system. Unfortunately, we do not have more detailed data that would permit us to determine exactly the extent to which these firms depended upon revenues from the 'dual-rate routes.' Nonetheless, the evidence suggests that U.S. Lines and Moore-McCormack especially depended upon such routes. Moreover, the lines that make up our sample were among the highest cost lines in the international liner shipping industry. It was widely held among industry experts and trade publications that if dual-rate contracts would be abolished, they would suffer the consequences disproportionately. ${ }^{28}$

We calculated weekly stock returns, corrected for stock dividends for each of the sample firms. From these data we constructed equally weighted indexes as well as indexes in which firms are weighted based upon their participation in conferences that employ dual-rate contracts.

We attempted to obtain stock returns for independent, non-conference carriers as well. If the hypothesis that exclusive contracts contributed to market power were correct, the prohibition of their use would have had a positive impact on independent carriers' stock returns. Unfortunately, stock price data for independent carriers are not available during our period of study. Most of these firms were closely held, often dominated by a single individual or family (like Isbrandtsen).

In addition, it is logical that any market power or efficiencies achieved by the conference carriers would have an impact on customers. If dual-rate

\footnotetext{
${ }^{28}$ See, for example, the comments of Senator Estes Kefauver in U.S. Senate, Doc. No. 100 (1962), p. 295; Congressional Record, September 13 1961, p. 18168.
} 
TABLE IV

Definition of DichotomousVariables

\begin{tabular}{|c|c|c|}
\hline Variable & Event & $\begin{array}{l}\text { Expected Sign } \\
\text { for Carriers }\end{array}$ \\
\hline Court 1 & $\begin{array}{l}\text { US District Court rules for Isbrandtsen in } \\
\text { North Atlantic case (March 21, 1951). }\end{array}$ & - \\
\hline Court 2 & $\begin{array}{l}\text { Supreme Court rules in North Atlantic and } \\
\text { Far East cases (March 10, 1952). }\end{array}$ & + \\
\hline Court 3 & $\begin{array}{l}\text { Supreme Court grants certiorari in Japan-Atlantic } \\
\text { case (March 25, 1957). }\end{array}$ & + \\
\hline Court 4 & $\begin{array}{l}\text { Supreme Court rules for Isbrandtsen. Bill introduced } \\
\text { in Congress to temporarily legalize dual-rate contracts } \\
\text { (May 19, 1958). }\end{array}$ & $\begin{array}{c}+/-(+ \text { if legislative event } \\
\text { dominates; }- \text { of judicial } \\
\text { event dominates })\end{array}$ \\
\hline Legislative 1 & $\begin{array}{l}\text { Bill introduced in Congress to permanently legalize } \\
\text { dual-rate contracts (February } 15,1961) \text {. }\end{array}$ & + \\
\hline Legislative 2 & $\begin{array}{l}\text { House Merchant Marine Committee reports bill } \\
\text { that would restrict dual-rate contracts (May } 4,1961 \text { ). }\end{array}$ & - \\
\hline Legislative 3 & $\begin{array}{l}\text { White House signals that President Kennedy will } \\
\text { not veto (September 29, 1961). }\end{array}$ & + \\
\hline
\end{tabular}

contracts contributed to market power and did not confer efficiency gains that outweighed this negative effect, then the increased freight rates would have been more harmful to industries for which exports constituted a relatively high percentage of industry sales.

Standard and Poor published a large number of industry level stock indexes in the 1950s and 1960s. ${ }^{29}$ We gathered weekly index values for industries that produced goods shipped by sea. The industry indexes are not created from the stock prices of all firms in an industry, but rather only those publicly traded firms chosen by Standard and Poor. These firms tended to be the largest and most important firms in an industry. The results that follow may not hold for small firms (more below). We then assembled data on U.S. foreign trade and total output of these industries' products, calculating net exports as a percentage of total production for each industry. ${ }^{30}$ Finally, we

${ }^{29}$ The stock price indexes are from Standard and Poor's Trade and Securities, Security Price Index Record. The list of the industries includes: Agricultural Machinery, Aluminum, Automobiles, Beverages-Brewers, Beverages-Distillers, Beverages-Soft Drinks, Building Materials-Cement, Carpets and Rugs, Chemicals, Confectionery, Containers-Metal and Glass, Containers-Paper, Drugs, Electrical Equipment, Electrical Household Appliances, Food-Dairy Products, Food-Meat Packing, Machine Tool Builders, Machinery-Specialty, Metal Fabricating, Office and Business Equipment, Paper, Railroad Equipment, Rayon \& Acetate Yarn, Shoes, Soaps, Steel, Textiles-Apparel, Textiles-Weavers, Tires and Rubber Goods, Tobacco-Cigarette Manufacturers, Vegetable Oils.

${ }^{30}$ The foreign trade data are from the U.S. Department of Commerce, Foreign Commerce and Navigation of the United States, 1946-1963. The output data are from the U.S. Census of Manufactures, 1963, Volume 1. All output and trade data are for the year 1963, the available data closest to our sample. In calculating net exports for each industry, we omitted all trade between the United States and Canada for these products, the preponderance of which travels by land. Trade, output and freight data were matched using Standard International Trade Classification codes and product descriptions in the primary sources. 
obtained data on freight costs as a percent of the value of each industry's exports in order to examine the hypothesis that industries with especially high freight costs would be more negatively affected by dual-rate contracts than other industries. ${ }^{31}$ We used these data to construct indexes in which we weighted individual industries based upon net exports, freight costs, or a combination of the two. We also identified specific industries that should have been especially sensitive to changes in freight rates: industries that either exported or imported a substantial portion of their output, and/or where freight rates constituted an especially large percentage of the value of the goods produced.

The events that we selected are shown in Table IV. The first four are important steps in the legal proceedings while the last three are important legislative developments. Table IV also presents the expected sign for each event under the hypothesis that dual-rate contracts did indeed bestow additional profitability to the sample ocean carriers and that the event was not fully anticipated.

\section{RESULTS}

We estimate equation (1) for an index of the shipping industry, individual shipping companies, indexes of exporting industries and individual industries, as well as for different specifications of the event window. In all cases we use the Standard and Poor's composite index, the most broadly based portfolio available, for the market return, $R_{m t}$. In addition, we apply the Newey-West methodology to estimate the standard errors that allows for autocorrelation. After calculating the Ljung-Box Q statistic for autocorrelation we allow up to a maximum of three lags. ${ }^{32}$

Table $\mathrm{V}$ presents the results of regressions of an index of the three shipping companies, in which each firm receives a weight corresponding to the percentage of conferences in which the firm participates that employ dualrate contracts. ${ }^{33}$ The one week specification provides clearly superior results in terms of statistical significance, which is not surprising since larger event windows may encompass additional important events unrelated to dual-rate contracts. In the one week specification, furthermore, the signs of the coefficients support the contention that dual-rate contracts were highly

\footnotetext{
${ }^{31}$ We thank David Hummels for providing us with these data. These data are from the U.S. Census, and are for 1994. It is reasonable to assume that the relative importance of freight costs for these industries was similar during the period of our study, because the ratio is closely related to products' physical characteristics.

${ }^{32}$ See Hayashi [2000]. Furthermore, we tested the equations for unit roots using the approach of Dickey and Fuller - the series were integrated of order zero. This confirms the suspicion that with data of this nature stationarity problems would not be an issue.

${ }^{33}$ We conducted the estimations using an equally weighted index and the results are consistent with those presented in Table V. Those results are available upon request.
} 
TABLEV

SHIPPING INDUSTRY. WEIGHTED INDEX

\begin{tabular}{lccc}
\hline & \multicolumn{3}{c}{ Length of Event Window } \\
\cline { 2 - 4 } Variable & One Week & Three Weeks & Five Weeks \\
\hline Court 1 & $-0.012^{*}$ & $-0.006^{*}$ & -0.004 \\
& $(10.06)$ & $(4.25)$ & $(1.49)$ \\
Court 2 & $0.059^{*}$ & 0.006 & 0.003 \\
& $(65.34)^{*}$ & $(0.64)$ & $(0.38)$ \\
Court 3 & $0.004^{*}$ & -0.006 & $(1.09)$ \\
& $(3.92)^{*}$ & -0.001 & $-0.51)$ \\
Court 4 & $0.030^{*}$ & $(0.14)$ & $(0.010$ \\
& $(28.01)$ & 0.028 & 0.018 \\
Legislative 1 & $0.122^{*}$ & $(1.46)$ & $(1.21)$ \\
& $(121.57)$ & -0.013 & -0.005 \\
Legislative 2 & $-0.004^{*}$ & $(2.81)$ & $(0.64)$ \\
& $(22.83)$ & -0.014 & -0.007 \\
Legislative 3 & $0.027^{*}$ & $(1.92)$ & $(1.67)$ \\
& $(29.21)$ & & \\
\hline
\end{tabular}

Notes: Number of observations: 651.

$\mathrm{t}$-statistics in parentheses in absolute values.

"significant at less than the $1 \%$ level.

The index includes three companies: U.S. Lines, Moore-McCormack and American Export Lines, weighted by the percentage of conferences in which the firm participates that employ dual-rate contracts.

TABLEVI

INDIVIDUAL CARRIERS

\begin{tabular}{lccc}
\hline Variable & U.S. Lines & Moore-McCormack & American Export Lines \\
\hline Court 1 & $-0.021^{*}$ & $-0.017^{*}$ & $0.011^{*}$ \\
& $(15.29)$ & $(12.09)$ & $(6.61)$ \\
Court 2 & $0.011^{*}$ & $0.116^{*}$ & $0.008^{*}$ \\
& $(10.07)$ & $(101.77)$ & $(6.01)$ \\
Court 3 & $0.015^{*}$ & $0.006^{*}$ & $-0.017^{*}$ \\
& $(13.34)$ & $(5.47)$ & $(13.70)^{*}$ \\
Court 4 & $0.010^{*}$ & $0.028^{*}$ & $0.062^{*}$ \\
& $(7.04)$ & $(20.40)$ & $(39.20)$ \\
Legislative 1 & $0.067^{*}$ & $0.192^{*}$ & $0.053^{*}$ \\
Legislative 2 & $(51.34)$ & $(149.49)^{*}$ & $(36.46)$ \\
Legislative 3 & $-0.009^{*}$ & $-0.028^{*}$ & -0.066 \\
& $(5.02)$ & $(16.50)$ & $(31.65)$ \\
& $0.057^{*}$ & $0.027^{*}$ & $-0.015^{*}$ \\
\hline
\end{tabular}

Notes: Number of observations: 651.

$t$-statistics in parentheses in absolute values

"significant at less than the $1 \%$ level.

valuable to the ocean carriers. The coefficient for Court 4 deserves special mention, since the above interpretation of added profitability is valid if one believes that the legislative event (the congressional response to the Isbrandtsen decision) dominated the impact of the Supreme Court decision 
TABLEVII

INDUSTRY INDEXES

\begin{tabular}{lcccc}
\hline Variable & $(1)$ & $(2)$ & $(3)$ & $(4)$ \\
\hline Court 1 & $0.022^{*}$ & $0.016^{*}$ & $0.013^{*}$ & $0.021^{*}$ \\
& $(30.79)$ & $(18.79)$ & $(12.54)$ & $(20.67)$ \\
Court 2 & $-0.013^{*}$ & $-0.012^{*}$ & $-0.018^{*}$ & $-0.012^{*}$ \\
& $(23.25)$ & $(21.06)$ & $(21.43)$ & $(15.27)^{*}$ \\
Court 3 & $-0.015^{*}$ & $-0.013^{*}$ & $-0.027^{*}$ & $-0.017^{*}$ \\
& $(28.27)$ & $(21.33)$ & $(32.55)$ & $(21.96)$ \\
Court 4 & $-0.008^{*}$ & 0.001 & $-0.017^{*}$ & 0.000 \\
Legislative 1 & $(10.64)$ & $(0.38)$ & $(15.83)$ & $(0.09)^{*}$ \\
Legislative 2 & $-0.033^{*}$ & $-0.019^{*}$ & $-0.022^{*}$ & $-0.033^{*}$ \\
Legislative 3 & $(48.30)$ & $(27.24)$ & $(22.13)$ & $(33.07)$ \\
& -0.017 & -0.016 & -0.022 & -0.024 \\
& $(17.15)$ & $(15.81)$ & $(16.19)$ & $(17.24)^{*}$ \\
\hline
\end{tabular}

Notes: Number of observations: 651.

$t$-statistics in parentheses in absolute values.

"significant at less than the $1 \%$ level and sign opposite to shipping industry.

Columns:

(1) Index is a simple average, assigning a positive sign to exporters and a negative sign to importers.

(2) Industries are weighted by net exports.

(3) Industries are weighted by freight, assigning a positive sign to exporters and a negative sign to importers.

(4) Industries are weighted by net exports and freight.

itself. Even if one does not accept that explanation, the remaining events are all strongly suggestive of the value of dual-rate contracts. We hesitate to read too much into the actual magnitudes of these coefficients, as they may or may not be indicative of the relative importance of the events, because the degree to which each event was anticipated could have been quite different. ${ }^{34}$ Nonetheless, the largest of these coefficients, that for Legislative 1, is 0.122 , implying that dual-rate contracts had substantial impact on the firms.

We present results for the individual firms using a one week event window in Table VI, and they confirm the results from the index regressions. ${ }^{35} \mathrm{It}$ is interesting to note that U.S. Lines and Moore-McCormack, which participated in a higher percentage of conferences using dual-rate contracts than American Export Lines, have coefficients that are very much in agreement, and which strongly support the hypothesis that dual-rate contracts contributed to these firms' profitability. Of the three firms, the regressions on the stock returns of American Export Lines are the least consistent with that hypothesis.

\footnotetext{
${ }^{34}$ One possibility is that observers could have anticipated the court decisions if they were able to glean information from judges' questions on the dates when the cases were argued. Additional regression results, available on request, provide weak support for that hypothesis.

${ }^{35}$ Results for the three and five week specifications for the individual firms are consistent with the index results using those same event windows.
} 
TABLEVIII

MAIN EXPORTING AND HIGH FREIGHT COST INDUSTRIES

\begin{tabular}{lccccccc}
\hline Variable & $\begin{array}{c}\text { Agric. } \\
\text { Mach. }\end{array}$ & Chem. & $\begin{array}{l}\text { Mach.- } \\
\text { Specialty }\end{array}$ & $\begin{array}{c}\text { Office \& } \\
\text { Business Equip. }\end{array}$ & Paper & $\begin{array}{c}\text { Railroad } \\
\text { Equip. }\end{array}$ & $\begin{array}{c}\text { Rayon \& } \\
\text { Acetate Yarn }\end{array}$ \\
\hline Court 1 & 0.001 & $0.040^{*}$ & $0.008^{*}$ & $0.017^{*}$ & $0.021^{*}$ & $0.027^{*}$ & $0.017^{*}$ \\
Court 2 & $(1.10)$ & $(51.91)$ & $(7.14)$ & $(13.54)$ & $(24.62)$ & $(27.86)$ & $(12.80)$ \\
& $-0.010^{*}$ & $-0.007^{*}$ & $-0.012^{*}$ & $-0.006^{*}$ & $-0.015^{*}$ & 0.001 & $-0.022^{*}$ \\
Court 3 & $(13.28)$ & $(11.77)$ & $(14.60)$ & $(7.10)$ & $(21.08)$ & $(2.09)$ & $(21.44)$ \\
& $-0.012^{*}$ & $-0.013^{*}$ & $-0.011^{*}$ & $-0.004^{*}$ & $-0.018^{*}$ & $-0.004^{*}$ & $0.011^{*}$ \\
Court 4 & $(15.97)$ & $(22.74)$ & $(13.17)$ & $(5.05)$ & $(25.07)$ & $(5.22)$ & $(10.31)$ \\
& 0.030 & $-0.010^{*}$ & $-0.005^{*}$ & $-0.005^{*}$ & -0.001 & 0.001 & 0.001 \\
Legislative 1 & $(29.04)$ & $(11.96)$ & $(4.84)$ & $(5.49)$ & $(0.73)$ & $(1.44)$ & $(1.21)$ \\
Legislative 2 & 0.014 & $-0.022^{*}$ & 0.007 & $-0.020^{*}$ & $-0.010^{*}$ & 0.012 & $-0.048^{*}$ \\
& $(14.96)$ & $(29.05)$ & $(7.73)$ & $(21.25)$ & $(11.51)$ & $(14.72)$ & $(41.86)$ \\
Legislative 3 & -0.007 & -0.004 & -0.016 & -0.020 & 0.001 & $0.013^{*}$ & -0.006 \\
& $(5.35)$ & $(3.50)$ & $(11.14)$ & $(15.79)$ & $(1.15)$ & $(11.73)$ & $(4.09)$ \\
& $(26.16)$ & $(31.94)$ & $(0.71)$ & $(1.42)$ & $(17.56)$ & $(0.80)$ & $(2.44)$ \\
\hline
\end{tabular}

Notes: Number of observations: 651 .

$t$-statistics in parentheses in absolute values.

"significant at less than the $10 \%$ level and sign opposite to shipping industry.

In order to distinguish between market power and efficiency hypotheses, we examine the effect of these events on net exporting industries. Those results are presented in Table VII. In each case we use a one week event window. In column one, the dependent variable is an equally weighted index of all the industries' stock returns, where net exporting industries are assigned a positive sign and net importing industries are assigned a negative sign. ${ }^{36}$ The index best permits us to avoid the possibility that the coefficients are determined by idiosyncratic (industry-specific) shocks that are not related to the shipping industry. The coefficients are statistically significant, and the signs of the coefficients are opposite those of the shipping industry index (as reported in Table V) in every case except Legislative 2. The results strongly support the hypothesis that dual-rate contracts did augment market power, and if they did permit the carriers to achieve efficiencies, those benefits were not passed on to exporters in a sufficient degree to offset the effect of their increase in market power. Legislative 2 is the only event of the seven that is supportive of an efficiency explanation for dual-rate contracts.

\footnotetext{
${ }^{36}$ The large number of industries that we employ constitutes a non negligible fraction of the Standard and Poor's Composite Index. As a robustness check we ran the regressions in which we employed Standard and Poor's Railroad Index instead as the market index. The railroad index is a good instrument because it reflects fluctuations in economic activity with an impact on transportation, but it should not be affected by dual rate contracts. The results that we obtain using the railroad index are very similar to those with the composite index. Those results are available on the Journal of Industrial Economics website.
} 
TABLE IX

MAIN IMPORTING AND HIGH FREIGHT COST INDUSTRIES

\begin{tabular}{lcccccc}
\hline Variable & $\begin{array}{c}\text { Food - Meat } \\
\text { Packing }\end{array}$ & $\begin{array}{c}\text { Beverages }- \\
\text { Brewers }\end{array}$ & $\begin{array}{c}\text { Beverages }- \\
\text { Distillers }\end{array}$ & $\begin{array}{c}\text { Carpets } \\
\text { and Rugs }\end{array}$ & $\begin{array}{c}\text { Textiles }- \\
\text { Apparel }\end{array}$ & $\begin{array}{c}\text { Textiles - } \\
\text { Weavers }\end{array}$ \\
\hline Court 1 & 0.006 & 0.017 & 0.016 & 0.022 & 0.003 & 0.013 \\
Court 2 & $(5.72)$ & $(15.77)$ & $(19.89)$ & $(15.18)$ & $(2.57)$ & $(13.20)$ \\
& -0.003 & -0.010 & -0.015 & $0.023^{*}$ & $0.001^{*}$ & -0.002 \\
Court 3 & $(3.58)$ & $(12.30)$ & $(22.03)$ & $(20.96)$ & $(1.62)$ & $(2.30)$ \\
& -0.006 & -0.010 & -0.007 & $0.004^{*}$ & $0.015^{*}$ & $0.002^{*}$ \\
Court 4 & $(6.95)$ & $(12.52)$ & $(10.50)$ & $(3.62)$ & $(18.91)$ & $(3.26)$ \\
& $0.009^{*}$ & -0.009 & 0.000 & $0.050^{*}$ & $0.006^{*}$ & $0.007^{*}$ \\
Legislative 1 & $(9.14)$ & $(8.81)$ & $(0.06)$ & $(39.79)$ & $(6.92)$ & $(8.07)$ \\
& $0.029^{*}$ & -0.001 & $0.025^{*}$ & 0.053 & $0.013^{*}$ & $0.033^{*}$ \\
Legislative 2 & $(32.14)$ & $(0.95)$ & $(31.07)$ & $(45.18)$ & $(15.27)$ & $(38.03)$ \\
& $-0.011^{*}$ & $-0.010^{*}$ & 0.050 & 0.005 & 0.004 & 0.010 \\
Legislative 3 & $(8.93)$ & $(8.00)$ & $(44.58)$ & $(3.27)$ & $(3.36)$ & $(8.57)$ \\
& -0.025 & $0.045^{*}$ & -0.020 & -0.006 & -0.002 & -0.007 \\
& $(30.55)$ & $(53.01)$ & $(29.74)$ & $(5.30)$ & $(2.10)$ & $(8.97)$ \\
\hline
\end{tabular}

Notes: Number of observations: 651.

$t$-statistics in parentheses in absolute values.

"significant at less than the $10 \%$ level and same sign as shipping industry.

In the remaining columns, we present alternative indexes of industries. The industries are weighted by: industry net exports as a percentage of total industry output in column 2, freight rates as a percent of the value of their products in column 3 and both net exports and freight rates in column 4 . The results are very consistent with those obtained in column 1.

Table VIII contains results for some specific industries that are included in our sample. We selected these particular industries because they should be especially sensitive to the behavior of liner conferences. In each of these industries, net exports are at least two percent of total output and freight rates represent at least two percent of the total value of the products. That is to say, these net exporting industries all satisfy some minimum level of hypothesized sensitivity. Furthermore, each of the displayed industries fulfills at least one of the following additional criteria: freight costs are at least seven percent of the total value of their output (very high freight costs), net exports constitute at least seven percent of their sales (very dependent on exports), or both net exports and freight costs are greater than four percent of total value (a combination of relatively high freight costs and relative dependence on exports). The individual industry regressions are quite consistent with one another, both across industries and across events. Furthermore, the magnitudes of the coefficients make economic sense. The coefficients are nearly always smaller than those estimated for the ocean carriers, which is consistent with the view that dual-rate contracts provided a concentrated benefit to the ocean carriers and more dispersed costs among exporters. The industries especially supportive of the market power hypothesis are chemicals, office and business equipment, paper and rayon and acetate yarn. In each of those cases, the coefficients are significant and 
with the expected sign under the hypothesis of market power in five or six of the seven events, and are only significant and consistent with the efficiency hypothesis for at most one event. The industry of this group offering the weakest support is agricultural machinery. The results for that industry support the market power and efficiency hypotheses an equal number of times. $^{37}$

In Table IX we present results for corresponding net importing industries - industries that follow similar criteria to those of industries in Table VIII: net imports are at least two percent of total output and freight rates represent at least two percent of the total value of the products, and industries must fulfill at least one of the following additional criteria: freight costs are at least seven percent of the total value of their output, net imports constitute at least seven percent of their sales, or both net imports and freight costs are greater than four percent of total value. Net importing industries should have benefited from dual rate contracts had they contributed to market power. Thus, the signs of the coefficients would be the same as those for the ocean carriers. But the results for these industries are far less supportive of the market power hypothesis than those for net exporting industries. With the exception of the beverage industries, there is evidence for market power for three of the events (Court 3, Court 4, and Legislative 1). The results for the other events are more supportive of the efficiency hypothesis, however. One possible explanation for the more equivocal results is due to the fact that the firms making up the indexes are large corporations. In any given industry, the largest firms tend to account for most exports. ${ }^{38}$ It is highly probable, therefore, that the firms making up our indexes are larger exporters than other firms in their respective industries. This means that even in industries that are net importers, the firms in our sample may export significant quantities. On average, firms in net importing industries should still depend less on exports (and compete more with imports) than firms in net exporting industries. Ideally, we would like to have exports by firm or the distribution of exporter firm size by industry, but those data are not available.

Although the data consist only of large firms, any effects of market power were probably more severe, not less, for small firms. Contemporary observers noted that this was almost certainly true, because small firms are less able to negotiate with carriers for concessions. ${ }^{39}$

\footnotetext{
${ }^{37} \mathrm{We}$ also conducted estimations for the industries that do not meet the criteria discussed above. Those industries should not have been nearly as sensitive to the events because of their relative lack of export intensity or the relative unimportance of freight rates as a percent of the value of their products. Not surprisingly, those estimations are not nearly as supportive of the market power hypothesis as the ones on the industries selected in Table VIII. Those additional results are available upon request.

${ }^{38}$ U.S. Department of Commerce (1999).

${ }^{39}$ U.S. House Subcomm. on Antitrust (1962), pp. 206-7.
} 
The econometric evidence strongly supports the contention that dual-rate contracts were beneficial to ocean carriers, and detrimental to their customers. The evidence validates the concerns expressed by the courts and the U.S. Department of Justice, as well as the complaints by numerous exporters as expressed in the congressional hearings. ${ }^{40}$

\section{CONCLUSIONS}

Loyalty contracts are one of the main features that have characterized the shipping industry for more than one hundred years. Several theoretical contributions have shown the potentially strong anti-competitive effects of these practices. In this paper we apply the event study methodology to study the evolution of firms' returns during the 1950s, a period of regulatory instability in the industry. The results indicate that loyalty (dual-rate) contracts improved ocean carriers' financial performance, and that the contracts enabled carriers' to exploit market power to the disadvantage of their customers.

Exclusive contracts are an important issue in competition policy that has received considerable theoretical attention, but relatively few empirical treatments. The evidence from ocean shipping supports theoretical arguments that such contracts convey market power.

\section{REFERENCES}

Aghion, P. and Bolton, P., 1987, 'Contracts as a Barrier to Entry', American Economic Review, 77, pp. 388-401.

Barron's, various issues.

Bennathan, E. and Walters, A. A., 1969, The Economics of Ocean Freight Rates (Praeger, New York).

Bernheim, D. and Whinston, M., 1998, 'Exclusive Dealing', Journal of Political Economy, 106 , pp. 64-103.

Binder, J., 1985, 'Measuring the Effects of Regulation with Stock Price Data', Rand Journal of Economics, 16, pp. 167-83.

Bork, R.H., 1978, The Antitrust Paradox: A Policy at War with Itself (Basic Books, New York).

Congressional Record, various volumes.

Director, A. and Levi, E. H., 1956, 'Law and the Future: Trade Regulation', Northwestern University Law Review, 51, pp. 281-96.

Fama, E.; Fisher, L.; Jensen, M. and Roll, R., 1969, 'The Adjustment of Stock Prices to New Information', International Economic Review, 10, pp. 1-21.

Fisher Ellison, S. and Mullin, W., 1995, 'Economics and Politics: The Case of Sugar Tariff Reform', Journal of Law and Economics 38, pp. 335-66.

Hayashi, F., 2000, Econometrics (Princeton University Press, Princeton).

${ }^{40}$ For example, see the comments of the president of the most important U.S. trade association representing exporters, the National Industrial Traffic League. Journal of Commerce, March 28 1961, pp. 1, 12. 
Heide, J. B.; Dutta, S. and Bergen, M., 1998, 'Exclusive Dealing and Business Efficiency: Evidence from Industry Practice', Journal of Law and Economics, 41, pp. 387-407.

Hummels, D., 2001, 'Toward a Geography of Trade Costs', unpublished manuscript.

Innes, R. and Sexton, R., 1994, 'Strategic Buyers and Exclusionary Contracts', American Economic Review, 84, pp. 566-84.

Journal of Commerce, various issues.

Klemperer, P., 1987, 'The Competitiveness of Markets with Switching Costs', Rand Journal of Economics, 18, pp. 138-50.

MacKinlay, A. C., 1997, 'Event Studies in Economics and Finance', Journal of Economic Literature, 35, pp. 13-39.

McGee, J. S., 1960, 'Ocean Freight Rate Conferences and the American Merchant Marine', University of Chicago Law Review, 27, pp. 191-314.

Marvel, H., 1982, 'Exclusive Dealing', Journal of Law and Economics, 25, pp. 1-25.

Mullin, G.; Mullin, J. and Mullin, W., 1995, 'The Competitive Effects of Mergers: Stock Market Evidence from the U.S. Steel Dissolution Suit', Rand Journal of Economics, 26, pp. 314-30.

Ornstein, S., 1989, 'Exclusive Dealing and Antitrust', The Antitrust Bulletin, 34, pp. 65-98.

Pirrong, S. C., 1992, 'An Application of Core Theory to the Analysis of Ocean Shipping Markets', Journal of Law and Economics, 35, pp. 89-131.

Podolny, J. and Scott Morton, F., 1999, 'Social Status, Entry and Predation: The Case of British Shipping Cartels, 1879-1929', Journal of Industrial Economics, 47, pp. 41-67.

Posner, R., 1976, Antitrust Law: An Economic Perspective (University of Chicago Press, Chicago).

Ramseyer, J. M., Rasmusen E. and Wiley, J. Jr., 1991, 'Naked Exclusion', American Economic Review, 81, pp. 1137-45.

Rose, N., 1985, 'The Incidence of Regulatory Rents in the Motor Carrier Industry', Rand Journal of Economics, 16, pp. 299-318.

Schwert, G. W., 1981, 'Using Financial Data to Measure Effects of Regulation', Journal of Law and Economics, 24, pp. 121-58.

Scott Morton, F., 1997, 'Entry and Predation: British Shipping Cartels, 1879-1929', Journal of Economics and Management Strategy, 6, pp. 679-724.

Sjostrom, W., 1989, 'Collusion in Ocean Shipping: A Test of Monopoly and Empty Core Models', Journal of Political Economy, 97, pp. 1160-79.

Sjostrom, W., 1988, 'Monopoly Exclusion of Lower Cost Entry', Journal of Transport Economics and Policy, 22, pp. 339-44.

Slade, M., 1998, 'Beer and the Tie: Did Divestiture of Brewer-Owned Public Houses Lead to Higher Beer Prices?', Economic Journal, 108, pp. 565-602.

Standard and Poor's Trade and Securities, Security Price Index Record, 1960-1968.

U.S. Department of Commerce, 1966, 1963 Census of Manufactures, Washington, D.C.

U.S. Department of Commerce, 1964, Foreign Commerce and Navigation of the United States, 1946-1963, Washington, D.C.

U.S. Department of Commerce, 1999, Small and Medium Sized Exporting Companies: A Statistical Profile, Washington, D.C.

U.S. House of Representatives, Committee on Merchant Marine and Fisheries, 1914, Steamship Agreements and Affiliations in the American Foreign and Domestic Trade, Document No. 805, 63d Cong., 2d Sess., Washington, D.C.

U.S. House of Representatives, Special Subcommittee on Steamship Conferences, 1959, Hearings. 86th Cong., 1st Sess., Washington, D.C.

U.S. House of Representatives, Subcommittee on Antitrust, 1962, The Ocean Freight Industry, Report No. 1419, 87th Cong., 2d Sess., Washington, D.C. 
U.S. Senate, 1962, Index to the Legislative History of the Steamship Conference/Dual-rate Law, Document No. 100, 87th Cong., 2nd Sess., Washington, D.C.

U.S. Senate, Committee on Commerce, 1961, Steamship Conferences and Dual-rate Contracts, Report No. 860, 87th Cong., 1st Sess., Washington, D.C.

Viard, V. B., 2002, 'Do Switching Costs Make Markets More or Less Competitive?: The Case of 800-Number Portability', Stanford University Graduate School of Business, working paper.

Yamey, B. S., 1972, 'Predatory Price Cutting: Notes and Comments', Journal of Law and Economics, 15, pp. 129-42.

Yong, J. S., 1996, 'Excluding Capacity-Constrained Entrants through Exclusive Dealing: Theory and an Application to Ocean Shipping', The Journal of Industrial Economics, 44, pp. 115-29. 